\title{
Hormonal requirements for the growth and differentiation of hamster preantral follicles in long-term culture
}

\author{
S. K. Roy and G. S. Greenwald \\ Department of Physiology, University of Kansas Medical Center, Ralph L. Smith Research Center, \\ Kansas City, KS 66103, USA
}

\begin{abstract}
Summary. Preantral follicles from pro-oestrous and oestrous hamsters were isolated enzymically (Stages 1-5) and by microdissection (Stage 6) and cultured for up to $168 \mathrm{~h}$ in the absence or presence of $100 \mathrm{ng}$ ovine FSH or LH separately or combined or 1 or $10 \mu \mathrm{g}$ progesterone or oestradiol-17 $\beta$ in serum-free defined medium and exposed to $1 \mu \mathrm{Ci}\left[{ }^{3} \mathrm{H}\right]$ thymidine for $24 \mathrm{~h}$ before termination. In the presence of insulin and hydrocortisone but not gonadotrophins, the morphology of follicles from pro-oestrous animals at Stages 1-4 (1-4 layers granulosa cells; no theca) were unaffected for up to $48 \mathrm{~h}$ whereas for Stages 5 (5-6 layers granulosa cells and developing theca) and 6 (7-8 layers granulosa cells and theca), atresia was prominent by $24 \mathrm{~h}$. FSH significantly reduced the percentage of atretic follicles in Stages $1-5$ throughout the culture period; but was effective only up to $96 \mathrm{~h}$ for Stage- 6 follicles. $\mathrm{LH}$ was also effective, albeit to a lesser extent. FSH increased follicular labelling indexes during every $24-\mathrm{h}$ labelling period and, during a pulse-chase period, follicular DNA content and granulosa cell numbers. FSH, but not $\mathrm{LH}$, induced differentiation by $96 \mathrm{~h}$ of preantral follicles at Stage 6 into small antral stages (Stages 7-8). FSH and LH together induced almost the same effect as FSH alone. However, neither progesterone nor oestradiol had any sig. nificant long-term effects on DNA synthesis and oestradiol induced atresia beyond $24 \mathrm{~h}$. Both FSH and $\mathrm{LH}$ induced follicular maturation in vitro as evident from increases in progesterone, androstenedione and oestradiol production. Follicles (Stages 1-4) collected from oestrous hamsters responded to FSH to a lesser extent than did those from pro-oestrous animals, possibly because of in-vivo exposure to periovulatory changes in gonadotrophins; however, an antrum formed in Stage- 6 follicles by $72 \mathrm{~h}$.
\end{abstract}

Keywords: preantral follicle; hamster; long-term culture; DNA synthesis; gonadotrophins

\section{Introduction}

The functions of follicular cells have been studied by incubating large preantral and antral follicles for brief periods (Hubbard \& Greenwald, 1982) or by culturing granulosa cells as a monolayer in the presence of various factors (Orly, 1984; Baranao \& Hammond, 1985; see review by GoreLangton \& Armstrong, 1988). However, disruption of the follicular microenvironment and in-vitro changes in cell shape (Ben-Rafael et al., 1987) may lead to altered responsiveness of granulosa cells to endocrine factors (Hammond \& English, 1987). Cellular maturation in parallel with follicular development from the primary to tertiary stages and its regulation by endocrine and paracrine factors remains mostly unexplored because it is impossible to monitor the growth of a given group of follicles in vivo since (1) folliculogenesis occurs as a continuum and (2) intact preantral follicles have not been cultured on a long-term basis. Using 2-h incubations, we have shown that follicular DNA synthesis in terms of $\left[{ }^{3} \mathrm{H}\right]$ thymidine incorporation is critically influenced by FSH and $\mathrm{LH}$ (Roy \& Greenwald, 1988); but in-vitro growth in terms of DNA synthesis and cell differentiation cannot be assessed by this system. 
Therefore, we have developed a long-term serum-free culture system which supports the growth and differentiation of intact hamster preantral follicles and provides a new dimension to studying the factors regulating folliculogenesis. Most of the study involved follicles from pro-oestrous hamsters because serum concentrations of FSH and LH were at their nadir and follicles were ready to respond to gonadotrophins (Roy \& Greenwald, 1986a, b, 1988). For comparison, in the final experiment follicles from oestrous hamsters which had already been primed with endogenous gonadotrophins were used. This was done to determine whether hormonal pre-exposure would accelerate follicle growth in vitro.

\section{Materials and Methods}

Collagenase (Type I), DNase (bovine pancreas), crystalline bovine serum albumin (BSA) and hydrocortisone were purchased from Sigma Chemical Co. (St Louis, MO, USA). Dulbecco's MEM (DMEM) was obtained from Gibco (Grand Island, NJ, USA); ITS ${ }^{+}$(insulin, transferrin, selenium and BSA) from Collaborative Research (Bedford, MA, USA) and bacteriological agar was from Difco Laboratory (Detroit, MI, USA). [ ${ }^{3} \mathrm{H}$ ]Thymidine (sp. act. $20 \mathrm{Ci} / \mathrm{mmol}$ ) was obtained from Amersham Corporation (Arlington Heights, IL, USA). All other analytical grade chemicals were from local sources.

Follicle preparation. Adult, virgin golden hamsters (90-100 g, Harlan, Madison, WI, USA) which had exhibited 3 consecutive oestrous cycles were killed at $09: 00 \mathrm{~h}$ on the day of pro-oestrus or oestrus. Preantral follicles at Stage 6 (7-8 layers of granulosa cells and developing theca) were dissected out and follicles in Stages 1-5 (Stages 1-4=1-4 layers of granulosa cells and no theca; Stage $5=5-6$ layers granulosa cells with the appearance of thecal cells in follicles with 6 layers) were enzymically dissociated (Roy \& Greenwald, 1985). After two sterile rinses in DMEM containing $15 \mathrm{~mm}-\mathrm{Hepes} / 0 \cdot 12 \% \mathrm{NaHCO}_{3}, 0.5 \% \mathrm{BSA}, 10^{3}$ units of penicillin $\mathrm{G}, 10 \mathrm{mg}$ streptomycin and $35 \mu \mathrm{g}$ fungizone (Hazelton, Lenexa, KS, USA) per ml of DMEM, follicles were collected in DMEM supplemented with $1 \%$ ITS $^{+}$ (final conc. $6.25 \mu \mathrm{g}$ insulin, $6.25 \mu \mathrm{g}$ transferrin, $6.25 \mu \mathrm{g}$ selenium, $1.25 \mathrm{mg}$ BSA and $5.35 \mu \mathrm{g}$ linoleic acid per ml) and 40 ng hydrocortisone per ml DMEM (DMEM-complete).

Follicle culture. Tissue culture plates ( 24 wells; Costar, Cambridge, MA, USA) were coated with $200 \mu 1$ sterile $0.625 \%$ agar in DMEM at $40^{\circ} \mathrm{C}$ to prevent attachment of follicles to the plastic surface and the formation of a monolayer. Groups of follicles at each stage were transferred at random to $300 \mu \mathrm{l}$ agar $\left(0.625 \%\right.$ in DMEM, $\left.40^{\circ} \mathrm{C}\right)$ added to each well. There were 30 Stage-1, 20-25 each of Stages 2-5, and 6-10 Stage-6 follicles per well. After gelation, $1 \mathrm{ml}$ DMEM-complete was added to each well. Follicles at each stage of development were distributed randomly into various groups and cultured at $37^{\circ} \mathrm{C}$ in $5 \% \mathrm{CO}_{2}$ in air in an humidified atmosphere for periods described in the experimental protocol.

Experiment 1. Follicles at Stages 1-6 were cultured for 96 or $168 \mathrm{~h}$ in (1) the absence (control) or presence of (2) $100 \mathrm{ng}$ ovine FSH (NIH-17)/ml, (3) $100 \mathrm{ng}$ ovine LH (NIH-25)/ml, (4) combined FSH and LH. Medium and hormones were replaced every $24 \mathrm{~h}$; cultures were terminated at $24,48,72,96,120,144$ and $168 \mathrm{~h}$ after adding $1 \mu \mathrm{Ci}$ $\left[{ }^{3} \mathrm{H}\right]$ thymidine $/ \mathrm{ml} 24 \mathrm{~h}$ before termination. Follicles were fixed in Bouin's fixative and $7 \mu \mathrm{m}$ thick sections were coated with NTB3 nuclear track emulsion (Kodak) and exposed for 7 days at $4^{\circ} \mathrm{C}$, developed in Dektol and stained with Gill's haematoxylin. Labelled nuclei (only densely labelled ones) and the number of atretic follicles (a minimum of 3-5 pycnotic nuclei) were counted at $\times 250$ magnification to determine the labelling index (LI) and the percentage of atretic follicles, respectively. Photographs of follicles cultured for up to $96 \mathrm{~h}$ are presented with the plane of focus emphasizing silver grains.

To determine whether there is an increase in follicular DNA content during the total period of in-vitro culture, follicles from pro-oestrous hamsters (Stages 1-6) were cultured in triplicate in the absence or presence of $100 \mathrm{ng}$ FSH for 24 to $168 \mathrm{~h}$ as described above and the culture was terminated every $24 \mathrm{~h}$. The follicles were sonicated in DNA assay buffer and DNA was estimated by fluorometry (Downs \& Wilfinger, 1983; Roy \& Greenwald, 1986a). The results were expressed as ng DNA per follicle.

Experiment 2. Follicles at Stages 1-6 were distributed randomly and treated as: (1) controls, (2) $100 \mathrm{ng} \mathrm{FSH} / \mathrm{ml}$, (3) $100 \mathrm{ng} \mathrm{LH} / \mathrm{ml}$ or combined FSH and $\mathrm{LH}$ and cultured for $96 \mathrm{~h}$. At the start of culture $1 \mu \mathrm{Ci}\left[{ }^{3} \mathrm{H}\right]$ thymidine was added to each group. The medium was changed every $24 \mathrm{~h}$ with full replacement of hormones and $2 \mu \mathrm{g}$ unlabelled thymidine/ $\mathrm{ml}$ to inhibit any possible incorporation of residual radioactivity remaining in the well. This dose of unlabelled thymidine blocked $\left[{ }^{3} \mathrm{H}\right]$ thymidine incorporation without hampering follicular growth. The cultures were terminated at $24,48,72$ and $96 \mathrm{~h}$ and follicles were processed for autoradiography as described above and labelled nuclei (both dense and light) were counted for indexing. We did not continue this experiment beyond $96 \mathrm{~h}$ because dilution of DNA-incorporated radionuclide introduced errors in counting. 
Experiment 3. Follicles were cultured for $96 \mathrm{~h}$ as (1) controls $(0 \cdot 1 \%$ ethanol); (2) 1 or $10 \mu \mathrm{g}$ progesterone and (3) 1 or $10 \mu \mathrm{g}$ oestradiol-17\%. The cultures were terminated at $24,48,72$ and $96 \mathrm{~h}$ after administration of $1 \mu \mathrm{Ci}$ $\left[{ }^{3} \mathrm{H}\right]$ thymidine $24 \mathrm{~h}$ before termination. Follicles were processed for autoradiography to monitor the labelling index.

Experiment 4. To monitor steroidogenesis, follicles at Stages 5 (30 follicles/replicate) and 6 (6 follicles/replicate) from pro-oestrous hamsters were cultured for $120 \mathrm{~h}$ in the absence or presence of $100 \mathrm{ng}$ FSH or LH separately or combined. Medium and hormones were replaced every $24 \mathrm{~h}$ and spent medium was assayed for progesterone, androstenedione and oestradiol-17 $\beta$ by RIAs as described by Terranova \& Greenwald (1978).

Analyses. The results were analysed by two-way analysis of variance and Duncan's multiple range test using Biomedical Data Package Programs (BMDP, CA) and Student's $t$ test with the level of significance at $5 \%$.

\section{Results}

\section{Experiment 1: role of gonadotrophins in maintaining follicular DNA synthesis and morphology}

No apparent difference in follicular morphology between control and hormone treated follicles from pro-oestrous hamsters at Stages 1-4 was observed up to $48 \mathrm{~h}$; however, the percentage of atretic follicles in the control group increased considerably by $72 \mathrm{~h}$ and for Stages 5 and 6 , atresia was prominent $(80 \%)$ by $24 \mathrm{~h}$ (Fig. 1) with $100 \%$ of Stage 6 follicles showing advanced atresia by $72 \mathrm{~h}$ (Figs $1 \& 2$ ). No attempt was made to classify the stage of atresia for small follicles because they contained few cells. For follicles at Stages 5 and 6, however, a clear zone of pycnosis around the oocyte was considered a sign of advanced atresia. In the presence of FSH or LH or combined treatment, a significant proportion $(\geq 80 \%$ ) of follicles at Stages $1-5$ remained free of pycnotic cells throughout the culture period but Stage- 6 follicles showed early pycnosis by $96 \mathrm{~h}$, regardless of hormonal treatment; none the less, overall follicular morphology was practically undisrupted compared to controls. Asynchrony in the ' $S$ ' phase was evident from the scattered distribution of densely labelled nuclei throughout the granulosa cell layer (Figs $2 a \& b$ ). For Stage-6 follicles, granulosa cells showing active DNA synthesis were orientated mainly around the oocyte. DNA synthesis was also detected in the developing thecal layer. At the light microscopic level, oocytes of FSH-exposed follicles appeared normal with intact germinal vesicles, nucleoli, homogeneous ooplasm (which was eosin stainable) and discrete oolemmal boundaries. Both insulin and hydrocortisone were essential for follicle culture; lack of insulin resulted in follicular degeneration within $24 \mathrm{~h}$ for all stages regardless of hormonal treatment (data not shown). Therefore, these two hormones were essential components of the medium. Moreover, the addition of selenium as an acceptor of free radicals generated during cell metabolism improved culture conditions.

During the first $24 \mathrm{~h}$ of FSH exposure, follicles from pro-oestrous hamsters at all stages showed marked increases in LI compared to controls (Fig. 2a); the degree of DNA synthesis varied for follicles at different stages of development. A significant increase in labelled nuclei was noticed by $24 \mathrm{~h}$ for Stage- 6 follicles in which $\geq 80 \%$ of cells were involved in DNA synthesis. By $96 \mathrm{~h}$, follicular morphology in the control group had deteriorated considerably, especially for Stage-6 follicles in which the labelling index dropped markedly and granulosa cell boundaries were obscured (Fig. 2b). FSH prevented cellular pycnosis; labelled cells, although few in number, were still visible for follicles at Stages 1-3 and significantly prominent for Stages 4 and 5. Preantral follicles at Stage 6 showed the first signs of differentiation with the appearance of antral cavities $(80-100 \%$ follicles developed antra; Fig. 2b). Although LH significantly increased labelled cells for Stages 5 and 6 (Fig. 2b), it failed to induce antrum formation in Stage-6 follicles.

Follicles from pro-oestrous hamsters at Stages 1-6 cultured for 24-168 h showed distinct labelling profiles (Fig. 3). In the absence of exogenous gonadotrophins, the LI for follicles at Stages 1 and 2 did not change appreciably during the first $48 \mathrm{~h}$ whereas for Stages 3 and 4 it declined steadily with the complete disappearance of labelled follicles by $96 \mathrm{~h}$. For Stages 5 and 6, there were no healthy labelled follicles by 48 and $24 \mathrm{~h}$, respectively. FSH, within $24 \mathrm{~h}$, significantly $(P<0.05)$ increased LI for Stages 1-6 and thereafter maintained it with ascending trends for most of the 


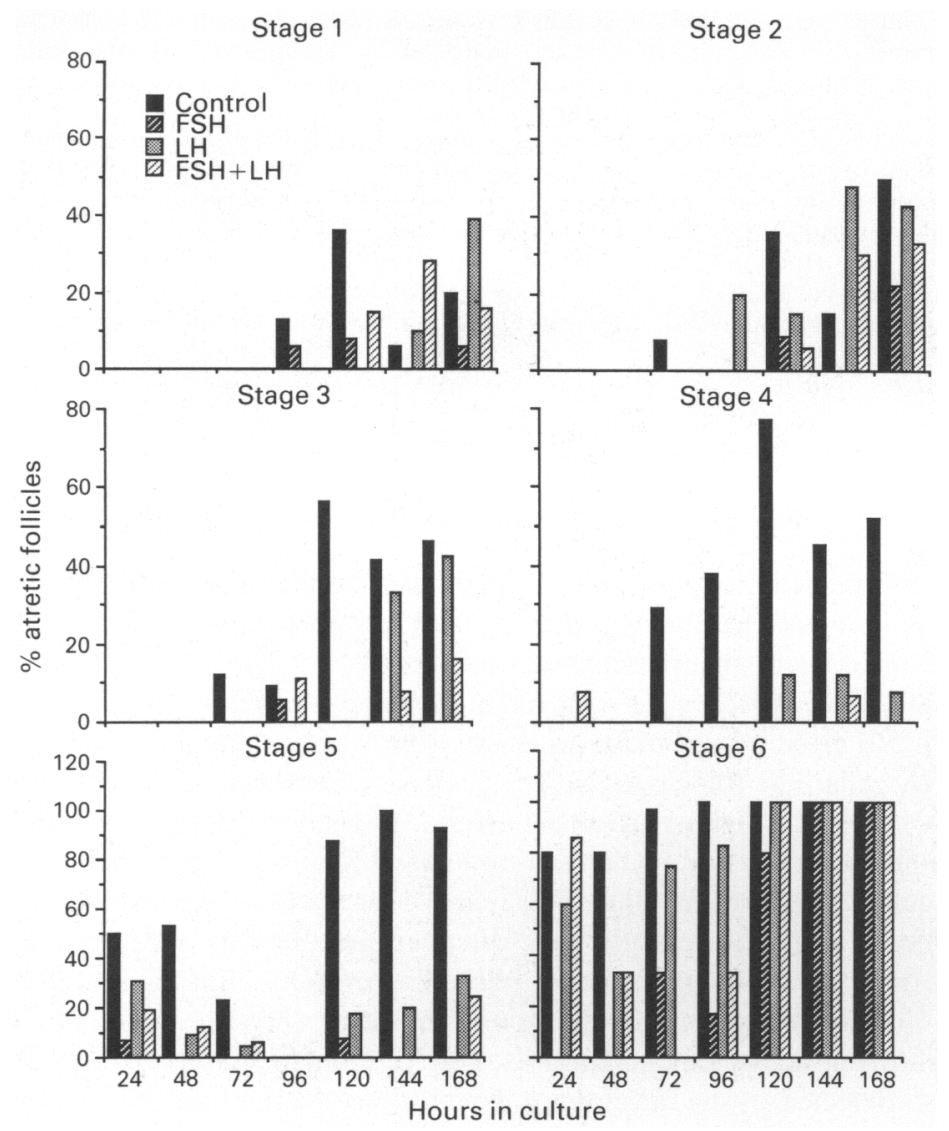

Fig. 1. Histogram showing the percentage of atresia in follicles from pro-oestrous hamsters, cultured in vitro for up to $168 \mathrm{~h}$ in the absence or presence of $100 \mathrm{ng}$ FSH or LH.

stages except for Stage 6 in which a gradual decline was evident. LH stimulated LI for Stages $1-4$ by 120-144 h and for Stages 5 and 6, by 24 and $72 \mathrm{~h}$, respectively.

Since FSH markedly influenced LI in vitro, follicular DNA content was estimated in the absence or presence of only FSH (Fig. 4). In the absence of FSH, DNA content of follicles from prooestrous animals either remained at steady low levels or gradually declined, correlating therefore with the previous findings on atresia (Fig. 1). Within $24 \mathrm{~h}$, FSH significantly increased DNA content for Stage 1-3 follicles while for Stages 4-6 a gradual increase was observed from $48 \mathrm{~h}$. On the whole, compared to $0 \mathrm{~h}$ values, follicular DNA content in FSH-exposed follicles at Stages 1-3 and 5-6 almost doubled, while in Stage-4 follicles there was a significant rise by 96-120 h; control groups remained low. To determine whether increased follicular DNA content correlates with increments in cell number, in a separate experiment follicles of Stages 1-6 were cultured as described earlier in the absence or presence of $100 \mathrm{ng}$ FSH for 5 days, fixed in Bouin's fixative, sectioned at $7 \mu \mathrm{m}$ and stained with haematoxylin and eosin. The number of cells in sections showing the oocyte nucleoli of individual follicles at Stages 1-6 were counted and compared with follicles obtained at 09:00 $\mathrm{h}$ on pro-oestrus (Day 4-0 h; Table 1). In the absence of FSH, cell number in follicles at Stages 1 and 3-4 remained virtually unchanged, while for Stages 5-6 degenerative changes were prominent. In Stage-2 follicles, however, there was a marked increase. Again, FSH not only maintained a significant number of healthy follicles after 5 days of culture, but also markedly increased cell number in Stages 1-5; Stage-6 follicles possessed a small antrum and some cells were pycnotic. 

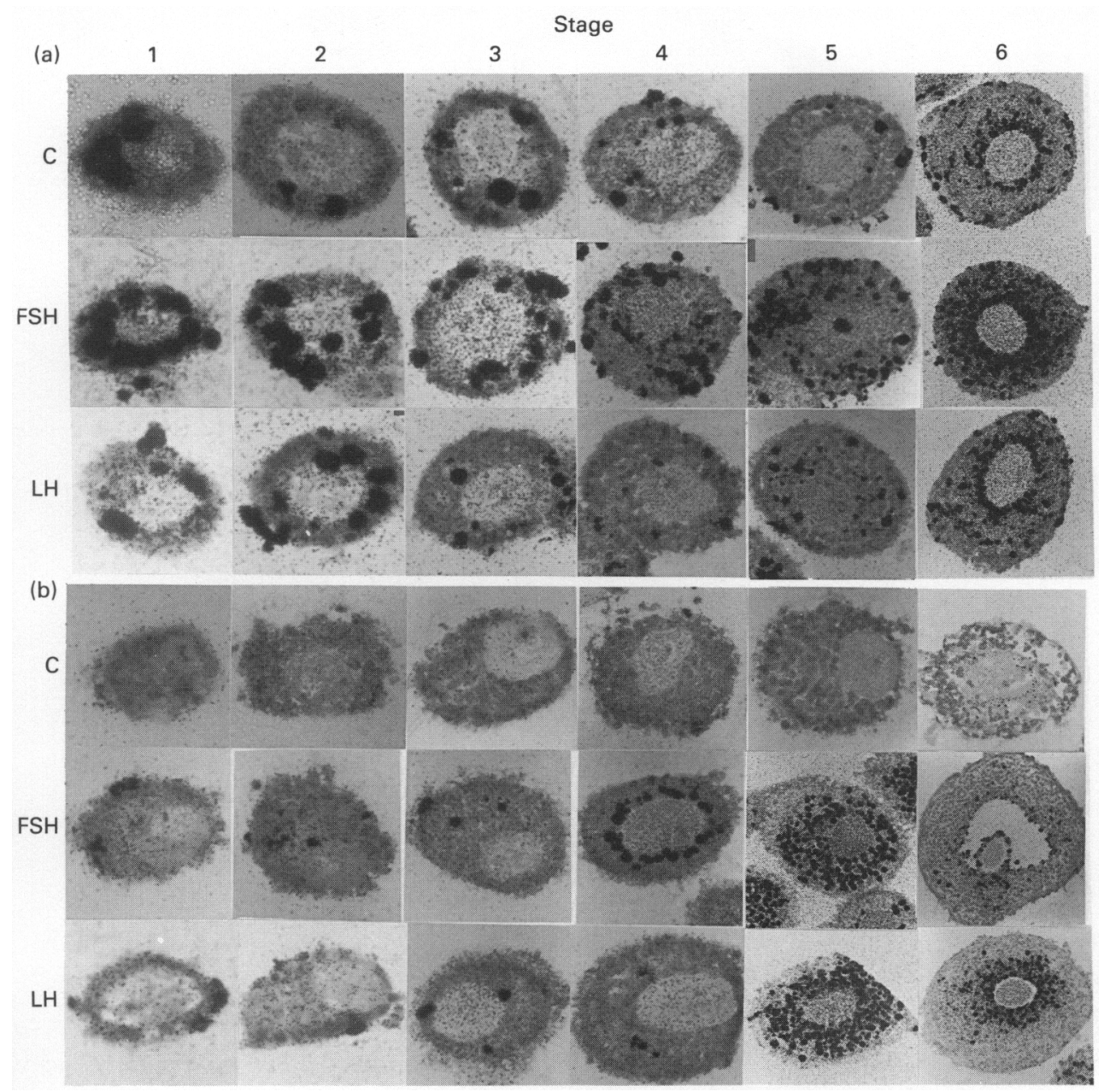

Fig. 2. Autoradiograms showing labelled pro-oestrous follicles at Stages 1-6 after (a) $24 \mathrm{~h}$ culture and (b) $96 \mathrm{~h}$ culture in the absence (C) or presence of $100 \mathrm{ng}$ FSH or LH. In (a) note active DNA synthesis in follicular cells as evident from dense silver grain deposit on the nuclei. In (b) note the formation of an antral cavity in Stage-6 follicle after exposure to $100 \mathrm{ng}$ FSH.

\section{Experiment 2: pulse-chase with $\left.{ }^{3} \mathrm{H}\right]$ thymidine to monitor follicular cell proliferation (Fig. 5)}

When pulsed with $\left[{ }^{3} \mathrm{H}\right]$ thymidine for $24 \mathrm{~h}$, all stages of follicles from pro-oestrous hamsters showed dense grain deposits in granulosa cell nuclei. Because of the dilution of radioactivity incorporated into DNA with each cell division, labelled cells with at least $\geq 20$ grains/nucleus were counted. As in Exp. 1, FSH significantly enhanced LI within $24 \mathrm{~h}$ for all stages and, thereafter, sustained a gradual ascent while the LI for hormone-deprived follicles either remained steady or declined during the $96 \mathrm{~h}$ of culture. LH, on the other hand, increased LI for all stages by the $24 \mathrm{~h}$ pulse period but thereafter maintained LI at low levels.

\section{Experiment 3: role of steroids in in-vitro follicular growth}

Progesterone $(1 \mu \mathrm{g})$ enhanced LI only for Stages 1 and 3 by $24 \mathrm{~h}$ but showed no long-term effect; the higher dose was ineffective. Oestradiol $(1$ or $10 \mu \mathrm{g})$ was completely ineffective in influencing follicular LI and, moreover, induced follicular atresia by $24 \mathrm{~h}$. 


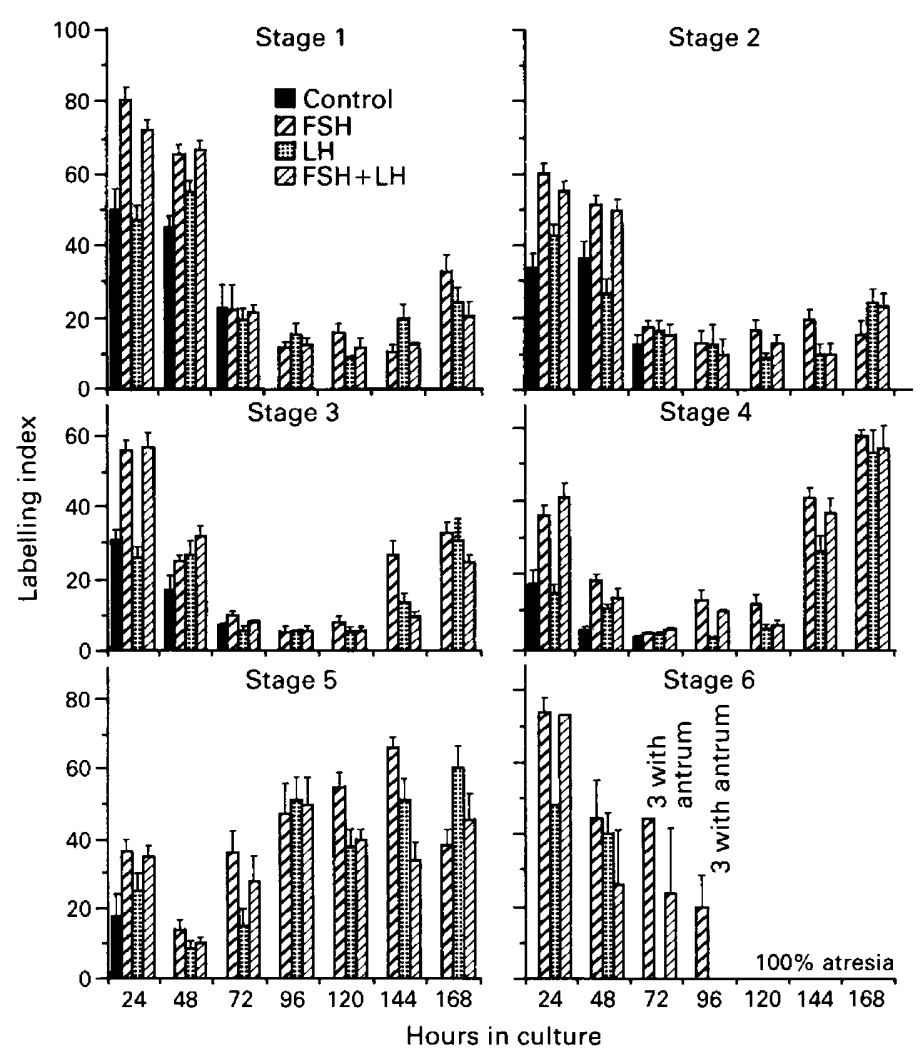

Fig. 3. Labelling indexes of pro-oestrous follicles at Stages 1-6 during $24-168 \mathrm{~h}$ culture in the absence or presence of $100 \mathrm{ng}$ FSH or LH.

Experiment 4: steroidogenesis by large preantral follicles of pro-oestrous hamsters in the absence or presence of FSH or LH (Table 2)

In the absence of gonadotrophins for $24 \mathrm{~h}$, Stage- 5 and -6 follicles accumulated low basal amounts of hormones and the values declined significantly by $120 \mathrm{~h}$, especially for Stage 6 . When stimulated by $100 \mathrm{ng}$ FSH, progesterone production by Stage- 5 follicles increased significantly by $24 \mathrm{~h}$ and increased further by $120 \mathrm{~h}$; for Stage- 6 follicles progesterone production remained steady. However, follicular androstenedione and oestradiol production were significantly stimulated by FSH at 24 and $120 \mathrm{~h}$. Because the culture medium was changed every $24 \mathrm{~h}$, the accumulation of steroids reflects an active conversion of respective precursors rather than a release of stored products.

LH, within $24 \mathrm{~h}$, stimulated progesterone production 4-fold for Stage-5 and 16-fold for Stage-6 follicles. Although LH significantly increased androstenedione production by Stage- 5 follicles, the values were far below those of the FSH-treated group; Stage- 6 follicles showed increased accumulation by $24 \mathrm{~h}$ and then dropped to lower levels by $120 \mathrm{~h}$ but were still at significantly higher levels than in controls. Accumulation of oestradiol also showed the same pattern as androstenedione. A combination of FSH and $\mathrm{LH}$ was also effective in stimulating follicular steroidogenesis but the pattern was similar to that for $\mathrm{LH}$ alone. Therefore, $\mathrm{LH}$ dampened the steroidogenic action of FSH.

For follicles from oestrous hamsters (Fig. 6), FSH increased LI for Stages 1 and 2 by $48 \mathrm{~h}$ and for Stages 3-6 by $24 \mathrm{~h}$ while controls showed a steady decline. However, at $24 \mathrm{~h}$ for Stages 1 and 2 
Stage 1
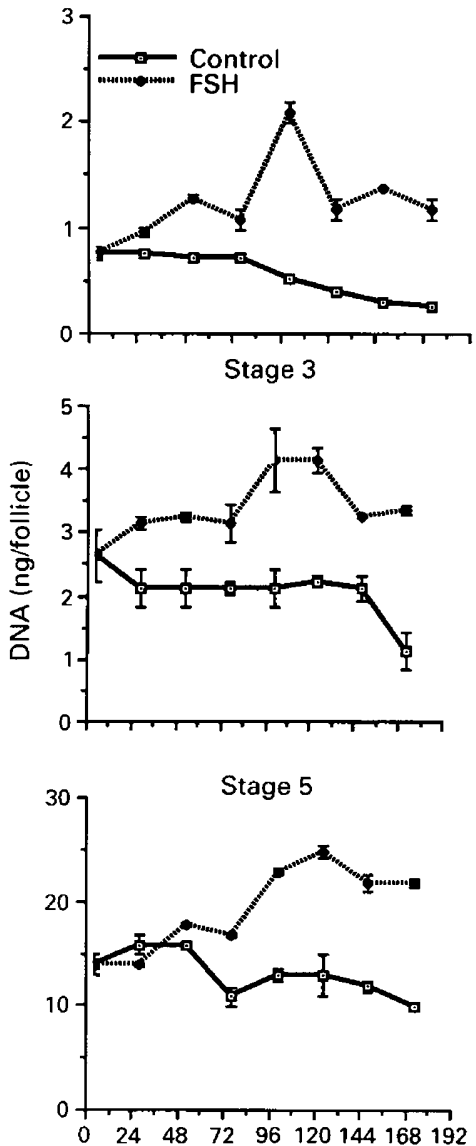

Stage 2
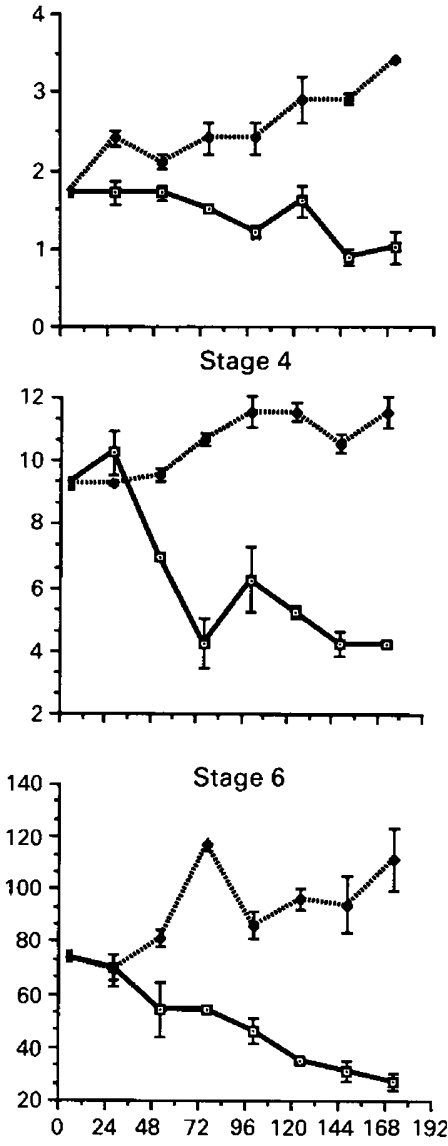

Hours in culture

Fig. 4. Follicular DNA content during long-term culture of hamster follicles with or without $100 \mathrm{ng}$ FSH.

Table 1. Number of cells in cross-sections of hamster follicles before and after in-vitro culture for 5 days

\begin{tabular}{lcccccc}
\hline & \multicolumn{6}{c}{ Stages of follicle } \\
\cline { 2 - 7 } Groups & 1 & 2 & 3 & 4 & 5 & 6 \\
\hline Day 4-0 h† & $12 \pm 0 \cdot 7$ & $20 \pm 0 \cdot 9^{*}$ & $40 \pm 3$ & $77 \pm 3$ & $110 \pm 4$ & $210 \pm 3$ \\
Control & $(11)$ & $(13)$ & $(11)$ & $(17)$ & $(15)$ & $(3)$ \\
& $14 \pm 0 \cdot 8$ & $31 \pm 1$ & $45 \pm 2$ & $70 \pm 6$ & atretic & atretic \\
FSH-100 ng & $(20)$ & $(22)$ & $(12)$ & $(5)$ & & \\
& $(15)$ & $(15)$ & $(15)$ & $(14)$ & $(10)$ & $(1)$ \\
\hline
\end{tabular}

Values are mean \pm s.e.m. for the no. of follicles indicated in parentheses.

${ }^{*} P<0.05$ compared with control value.

†Follicles collected from pro-oestrous hamsters and without culture.

$\ddagger$ Stage- 6 follicles had formed antrum and some contained pycnotic cells; therefore, cells were not counted. 


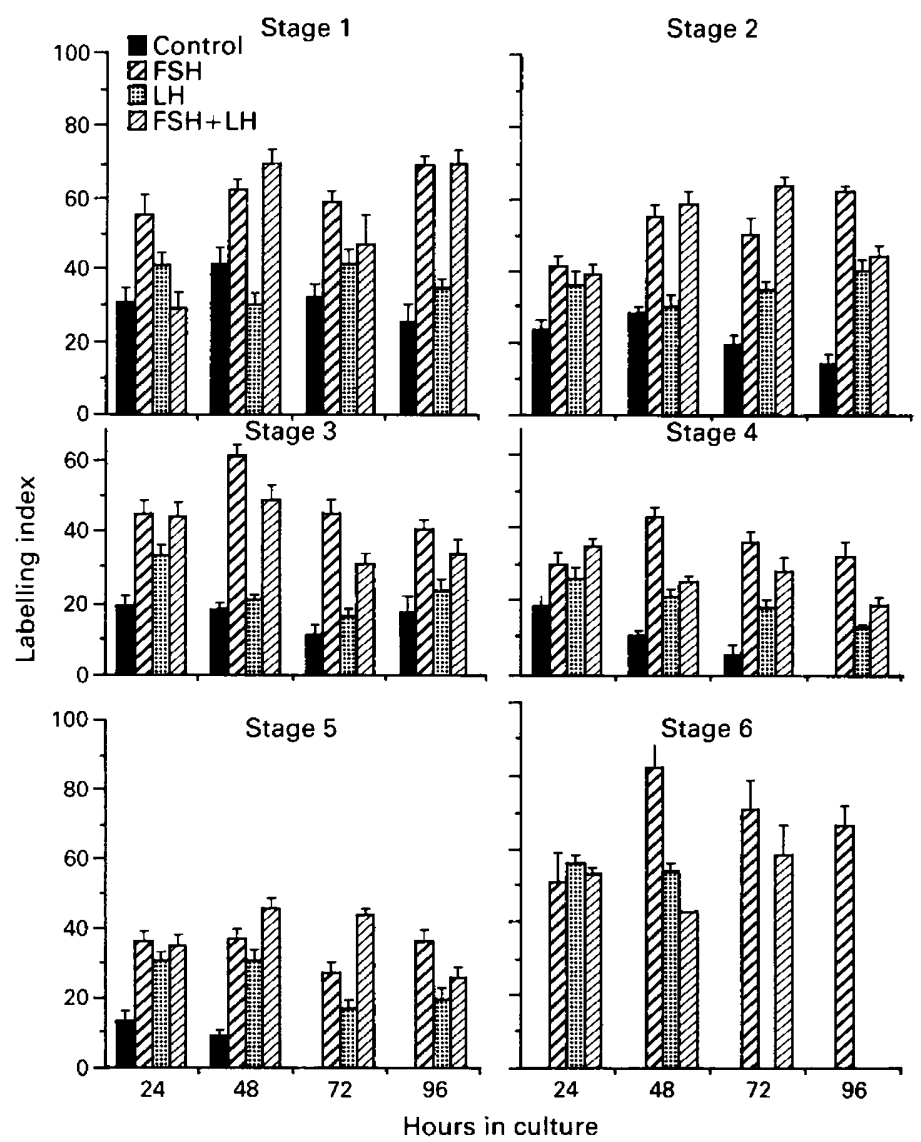

Fig. 5. Pulse-chase experiment with $\left[{ }^{3} \mathrm{H}\right]$ thymidine of pro-oestrous follicles during $96 \mathrm{~h}$ culture in the absence or presence of $100 \mathrm{ng}$ FSH or LH. Follicles were pulsed with radionuclide during the first $24 \mathrm{~h}$ and medium was then replaced every $24 \mathrm{~h}$ with DMEM containing $2 \mu \mathrm{g}$ unlabelled thymidine.

Table 2. Production in vitro of progesterone, androstenedione and oestradiol-17 $\beta$ by follicles, in longterm culture, from pro-oestrous hamsters

\begin{tabular}{|c|c|c|c|c|c|c|c|}
\hline \multirow[b]{3}{*}{ Group } & \multirow{3}{*}{$\begin{array}{l}\text { Time in } \\
\text { culture } \\
\text { (h) }\end{array}$} & \multicolumn{6}{|c|}{ Steroids (pg/follicle $/ 24 \mathrm{~h}$ ) } \\
\hline & & \multicolumn{2}{|c|}{ Progesterone } & \multicolumn{2}{|c|}{ Androstenedione } & \multicolumn{2}{|c|}{ Oestradiol } \\
\hline & & Stage 5 & Stage 6 & Stage 5 & Stage 6 & Stage 5 & Stage 6 \\
\hline Control & $\begin{array}{r}24 \\
120\end{array}$ & $\begin{array}{l}30 \pm 3 \\
15 \pm 1\end{array}$ & $\begin{array}{l}55 \pm 10 \\
14 \pm 3\end{array}$ & $\begin{array}{l}2 \pm 0 \cdot 4 \\
2 \pm 0 \cdot 4\end{array}$ & $\begin{aligned} 53 & \pm 6 \\
1 & \pm 0.2\end{aligned}$ & $\begin{array}{c}1 \pm 0.2 \\
0.5 \pm 0.06\end{array}$ & $\begin{array}{r}20 \pm 3 \\
3 \pm 1\end{array}$ \\
\hline $\begin{array}{l}\text { FSH } \\
(100 \mathrm{ng} / \mathrm{ml})\end{array}$ & $\begin{array}{r}24 \\
120\end{array}$ & $\begin{array}{l}207 \pm 0 \cdot 1^{*} \\
695 \pm 40^{*}\end{array}$ & $\begin{array}{l}299 \pm 58^{*} \\
304 \pm 36^{*}\end{array}$ & $\begin{aligned} 7 & \pm 2^{*} \\
241 & \pm 44^{*}\end{aligned}$ & $\begin{aligned} 215 & \pm 31^{*} \\
1885 & \pm 196^{*}\end{aligned}$ & $\begin{array}{c}5 \pm 1^{*} \\
1148 \pm 160^{*}\end{array}$ & $\begin{array}{c}46 \pm 5^{*} \\
2036 \pm 421^{*}\end{array}$ \\
\hline $\begin{array}{l}\text { LH } \\
(100 \mathrm{ng} / \mathrm{ml})\end{array}$ & $\begin{array}{r}24 \\
120\end{array}$ & $\begin{array}{c}585 \pm 69^{*} \\
2577 \pm 475^{*}\end{array}$ & $\begin{array}{l}2203 \pm 77^{*} \\
4771 \pm 949^{*}\end{array}$ & $\begin{array}{r}8 \pm 1^{*} \\
34 \pm 8^{*}\end{array}$ & $\begin{array}{l}770 \pm 93^{*} \\
116 \pm 12^{*}\end{array}$ & $\begin{aligned} 2 & \pm 0 \cdot 3^{*} \\
219 & \pm 31^{*}\end{aligned}$ & $\begin{aligned} & 15 \pm 2^{*} \\
& 196 \pm 27^{*}\end{aligned}$ \\
\hline $\begin{array}{l}\mathrm{FSH}+\mathrm{LH}(100+ \\
100 \mathrm{ng} / \mathrm{ml})\end{array}$ & $\begin{array}{r}24 \\
120\end{array}$ & $\begin{aligned} 936 & \pm 152^{*} \\
1453 & \pm 43^{*}\end{aligned}$ & $\begin{array}{l}1796 \pm 147^{*} \\
4442 \pm 197^{*}\end{array}$ & $\begin{aligned} 9 & \pm 1^{*} \\
24 & \pm 4^{*}\end{aligned}$ & $\begin{array}{c}498.1 \pm 187^{*} \\
100 \pm 9^{*}\end{array}$ & $\begin{aligned} 2 & \pm 0 \cdot 2^{*} \\
112 & \pm 14^{*}\end{aligned}$ & $\begin{array}{c}50 \pm 6^{*} \\
323 \pm 10^{*}\end{array}$ \\
\hline
\end{tabular}

Values are mean \pm s.e.m. for 4 replicates.

${ }^{*} P<0.05$ compared with the respective control. 
in control groups, LI was much higher than in the follicles from pro-oestrous hamsters at corresponding stages. For Stages 5 and 6, FSH significantly increased LI by $96 \mathrm{~h}$ and antrum formation was observed in Stage- 6 follicles by 72 h, 1 day earlier than in the follicles of pro-oestrous animals. Although LH maintained follicular viability for all stages, it was unable to induce antrum formation. FSH and LH together increased LI for Stages I-5; however, for Stage 6 LI decreased considerably.

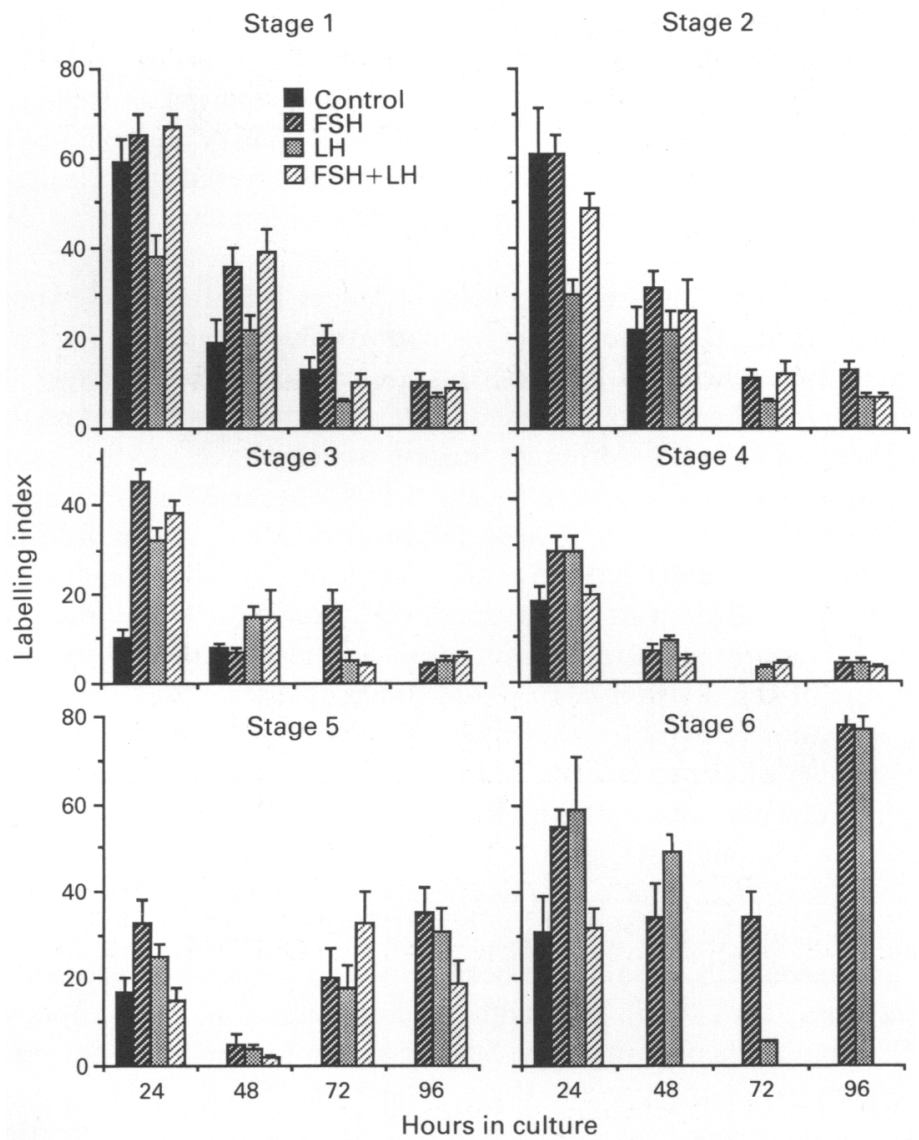

Fig. 6. Labelling indexes of oestrous follicles at Stages 1-6 during 24-96 h culture in the absence or presence of $100 \mathrm{ng} \mathrm{FSH}$.

\section{Discussion}

The results of the present studies provide evidence for an efficient long-term culture system (4-7 days) which supports the growth and differentiation of hamster preantral follicles. The presence of insulin in the culture is vital from the beginning to support follicular viability. However, in our system, insulin alone is insufficient to maintain healthy follicles (control, Fig. 4), suggesting the requirement for other factors for follicular survival.

In the hamster, FSH causes follicular recruitment in vivo (Kim \& Greenwald, 1984) and DNA synthesis in preantral follicles both in vivo (Roy \& Greenwald, 1986a, b) and in vitro (Roy \& Greenwald, 1988). The results of granulosa cell culture need to be interpreted with caution since 
extensive intercellular communication by gap junctions between granulosa cells as observed in vivo (Albertini \& Anderson, 1974) is virtually destroyed during harvesting of granulosa cells which may induce membrane perturbations resulting in premature activation of intracellular signals for differentiation and alterations in cell functions, and reappearance of gap junctions in vitro (Amsterdam et al., 1981) may not represent their counterparts in vivo.

Differentiation of Stage-6 preantral follicles to early antral stages (Stages 7-8) indicates the efficiency of the culture system to maintain large preantral follicles for at least 4 days. The failure to maintain Stage- 6 follicles beyond $96 \mathrm{~h}$ could be due to several factors: (1) Stage- 6 follicles are the immediate preantral pool to be recruited within 4 days to the next set of ovulatory follicles and so culturing them beyond $96 \mathrm{~h}$ may exceed their normal lifespan resulting in follicular atresia; (2) the complex cellular maturational processes accompanying growth may no longer be supported by the simple defined medium; or (3) because granulosa cells in multilayered follicles depend on diffusible products from thecal vascularity, growth in vitro may ultimately lead to cell death due to inaccessibility of nutrients.

The marked increases in LI by $24 \mathrm{~h}$ for follicles at Stages 1-6 after FSH exposure support our earlier in-vivo findings during the periovulatory gonadotrophin surges (Roy \& Greenwald, 1986a). The labelling pattern for follicles of pro-oestrous animals at different stages during the 168-h culture period indicates that the rates of growth of developing follicles depend on their maturational status at the time they are cultured. Although Stage- 6 follicles have 100-fold more DNA than do Stage-1 follicles, no such massive increase in follicular DNA occurred in any stage during the 7-day culture period. Chiras \& Greenwald (1977) have demonstrated that, in vivo, follicles with 2-3 layers of granulosa cells (Stages 2-3) take 8 days to acquire 4-5 layers of cells (Stages 4-5) while another 8 days is required to form a follicle with 7-8 layers of cells (Stage 6). Therefore, it takes 16 days for Stage-2 follicles to become Stage- 6 follicles in vivo. Considering the use of serum-free defined medium, a slower rate of cell division in vitro and different rates of cell proliferation in different stages of follicles, it cannot be expected that Stage-1 follicles will transform into Stage 6 within 7 days in vitro. The inability of LH to increase follicular labelling indexes by $24 \mathrm{~h}$ for follicles smaller than Stage 5 supports our previous findings (Roy \& Greenwald, 1986b, 1988). Follicles at Stages 1-4 do not possess any LH binding sites or LH-responsive adenylate cyclase which appear from Stage 5 and onwards (Roy et al., 1987; Roy \& Greenwald, 1988). LH-induced increases in LI for Stages 3 and 4 by $48 \mathrm{~h}$ could be due to the acquisition of LH receptors during in-vitro growth by insulin action on granulosa cells. Insulin has been shown to induce LH receptors in rat granulosa cells in culture (Davoren et al., 1986). Although, in short-term ( 2 h) incubation, LH counteracted FSH-induced $\left[{ }^{3} \mathrm{H}\right]$ thymidine incorporation by Stage- 5 and -6 follicles (Roy \& Greenwald, 1988), no such effect was discernible in the present study. The antagonistic effect may be limited to the preovulatory surge period or to a brief duration of in-vitro exposure, but thereafter the tonic levels induce follicular recruitment and maturation.

The low, steady labelling indexes for follicles in the control group for Stages 1-3 during the pulse-chase period indicates a cessation in cell proliferation; a sharp drop by $72 \mathrm{~h}$ for Stages 4 and 5 along with increased atresia may reflect the loss of radionuclide by DNA fragmentation. The characteristic increases in LI by 24 and $48 \mathrm{~h}$ due to FSH for most of the stages strongly suggests that cells which were actively synthesizing DNA by $24 \mathrm{~h}$ underwent mitosis. The decrease in LI from the $48 \mathrm{~h}$ value may reflect the proliferation of unlabelled cells during the chase period, thereby also affecting the percentage of labelled cells. The results of follicular DNA content and cell number support this view. The in-vitro increase in follicular DNA within $24 \mathrm{~h}$ for Stages 1-3 in the presence of FSH correlates well with the increase in $\left[{ }^{3} \mathrm{H}\right]$ thymidine incorporation (Roy \& Greenwald, 1986a, 1988) and LI, and provides convincing evidence that FSH stimulates follicular DNA synthesis and cell proliferation in small preantral follicles. The slow ascent in follicular DNA content following FSH exposure can be ascribed to asynchrony in cell division whereby only a few new cells are recruited every $24 \mathrm{~h}$ which may not add enough DNA to double the total content (considering 12 pg DNA per hamster granulosa cell and the maximum sensitivity of the assay is $10 \mathrm{ng} /$ tube: Roy 
\& Greenwald, 1986a). However, when the values between 0 and $168 \mathrm{~h}$ of culture are compared, a clear-cut rise in follicular DNA is evident by $96-120 \mathrm{~h}$. This is further substantiated by the rise in the number of follicular cells during the 120 -h culture period. Beyond $96 \mathrm{~h}$ the rise in DNA content for Stage 6 when granulosa cells undergo considerable degeneration may indicate the proliferation of thecal cells as well as the remainder of the viable granulosa cells. Incorporation of radioactivity by Stage-6 follicles at $144 \mathrm{~h}$ was seen in autoradiograms (data not shown).

The steady high LI for LH-exposed follicles at Stages 5 and 6 for up to $48 \mathrm{~h}$ during the chase period suggests that $\mathrm{LH}$ has a different influence on the cell cycle than does FSH. Increased $\left[{ }^{3} \mathrm{H}\right]$ thymidine incorporation by Stages 5 and 6 incubated with LH has been previously observed (Roy \& Greenwald, 1988). However, increased LI for Stage-5 follicles by $48 \mathrm{~h}$ and for Stage 6 by $72 \mathrm{~h}$ by combined FSH and LH suggests that both hormones are necessary for normal functioning of these stages. The mandatory requirements for both FSH and LH for the development of antral and preovulatory follicles in the hamster have already been demonstrated (Moore \& Greenwald, 1974; Kim \& Greenwald, 1984).

Oestradiol does not influence folliculogenesis in vivo either in the hamster (Kim et al., 1984) or in the monkey (Koering et al., 1986). The present in-vitro studies also demonstrate that oestradiol has no stimulatory effect on follicular DNA synthesis; however, slight stimulation by progesterone was evident.

Significant increases in steroidogenesis by follicles at Stages 5 and 6 after exposure to FSH suggest that the follicles are functionally active even after $120 \mathrm{~h}$ culture. Furthermore, the rise in androstenedione and oestradiol production by Stage 6 and oestradiol by Stage 5 after $120 \mathrm{~h}$ provides further evidence for FSH-induced follicular maturation in vitro; however, LH mainly affected progesterone production. Increases in progesterone, androstenedione and oestradiol accumulation by hamster follicles at Stages 5 and 6 during short-term $(2 \mathrm{~h})$ exposure to FSH and LH in vitro has been previously reported (Roy \& Greenwald, 1987). Luteinization of granulosa cells is associated with a shift in steroidogenesis towards progesterone (Channing, 1970). In the present study, LH causes thecal hyperplasia and differentiation (data not shown) leading to a gradual transformation of follicular cells to luteal-like cells with maximal progesterone production.

Although follicles of oestrous animals showed almost the same trend in DNA synthesis in response to gonadotrophins, the failure of those at Stages 1 and 2 to respond to FSH by $24 \mathrm{~h}$ could be due to refractoriness induced by the endogenous gonadotrophin surges. This was evident from the higher LI observed for follicles from oestrous compared to pro-oestrous hamsters and from our previous results (Roy \& Greenwald, 1986a). The faster rate of differentiation of follicles of oestrous animals due to FSH and LH priming is substantiated by the onset of antrum formation in Stage- 6 follicles by $72 \mathrm{~h}$.

This work was supported by a grant from NIH (HD00596). FSH and LH were provided by the National Pituitary Program of NIH.

\section{References}

Albertini, D.F. \& Anderson, E. (1974) The appearance and structure of intercellular connection during the ontogeny of the rabbit ovarian follicle with particular reference to gap junctions. J. Cell Biol. 63, 234-250.

Amsterdam, A., Knecht, M. \& Catt, K.J. (1981) Hormonal regulation of cytodifferentiation and intercellular communication in cultured granulosa cells. Proc. natn. Acad. Sci. USA 78, 3000-3004.

Baranao, J.L. \& Hammond, J.M. (1985) Serum free medium enhances the growth and differentiation of cultured pig granulosa cells. Endocrinology 116, 51-58.

Ben-Rafael, Z., Garcia, C.J., Meloni, F., Minda, D.,
Iozzo, R., Mastroianni, L., Jr \& Flickinger, G.L. (1987) Growth on floating collagen influences structure and steroid secretion of human granulosa cells. Proc. 34th A. Meeting, Society for Gynecologic Investigation, Atlanta, p. 95, abstr.

Channing, C.P. (1970) Influence of the in vivo and in vitro hormonal environment upon luteinization of granulosa cells in the tissue culture. Recent Prog. Horm. Res. 26, 589-622.

Chiras, D.D. \& Greenwald, G.S. (1977) An autoradiographic study of long-term follicular development in the cyclic hamster. Anat. Rec. 188, 331-338. 
Davoren, J.B., Kasson, B.G., Li, C.H. \& Hsueh, A.J.W. (1986) Specific insulin-like growth factor (IGF)I- and II-binding sites on rat granulosa cells: relation to IGF action. Endocrinology 119, 2155-2162.

Downs, T.R. \& Wilfinger, W.W. (1983) Fluorometric quantitation of DNA in cells and tissue. Analyt. Biochem. 131, 538-547.

Gore-Langton, R.E. \& Armstrong, D.T. (1988) Follicular steroidogenesis and its control. In The Physiology of Reproduction, vol. I, pp. 387-445. Eds E. Knobil \& J. Neill. Raven Press, New York.

Hammond, J.M. \& English, H.F. (1987) Regulation of deoxyribonucleic acid synthesis in cultured porcine granulosa cells by growth factors and hormones. Endocrinology 120, 1039-1046.

Hubbard, C.J. \& Greenwald, G.S. (1982) Cyclic nucleotides, DNA and steroid levels in ovarian follicles and corpora lutea of the cyclic hamster. Biol. Reprod. 26, $230-240$.

Kim, I. \& Greenwald, G.S. (1984) Hormonal requirements for maintenance of follicular and luteal function in the hypophysectomized cyclic hamster. Biol. Reprod. 30, 1063-1072.

Kim, I., Shaha, C. \& Greenwald, G.S. (1984) A species difference between hamster and rat in the effect of oestrogen on growth of large preantral follicles. $J$. Reprod. Fert. 72, 179-185.

Koering, M.J., Danforth, D.R. \& Hodgen, G.D. (1986) The effect of estrogen on preantral follicle growth in immature rats and monkeys. Biol. Reprod. 34 (Suppl. 1) 209 , abstr.

Moore, P.J. \& Greenwald, G.S. (1974) Effect of hypophysectomy and gonadotropin treatment on follicular development and ovulation in the hamster. Am.J. Anat. 139, 37-48.
Orly, J. (1984) Growth of functional primary and established rat ovary cell cultures in serum-free medium. In Methods for Serum-Free Culture of Cells of the Endocrine System, pp. 63-87. Eds D. W. Barnes \& D. A. Sirbaku. Alan R. Liss, Inc, New York.

Roy, S.K. \& Greenwald, G.S. (1985) An enzymatic method for dissociation of intact follicles from the hamster ovary: histological and quantitative aspect. Biol. Reprod. 32, 203-215.

Roy, S.K. \& Greenwald, G.S. (1986a) A quantitative analysis of in-vitro incorporation of $\left[{ }^{3} \mathrm{H}\right]$ thymidine into hamster follicle during the oestrous cycle. $J$. Reprod. Fert. 77, 143-152.

Roy, S.K. \& Greenwald, G.S. (1986b) Effects of FSH and LH on incorporation of $\left[{ }^{3} \mathrm{H}\right]$ thymidine into follicular DNA. J. Reprod. Fert. 78, 201-209.

Roy, S.K. \& Greenwald, G.S. (1987) In vitro steroidogenesis by primary to antral follicles in the hamster during the periovulatory period: effects of folliclestimulating hormone, luteinizing hormone and prolactin. Biol. Reprod. 37, 39-46.

Roy, S.K. \& Greenwald, G.S. (1988) In vitro effects of follicle-stimulating hormone, luteinizing hormone and prolactin on follicular deoxyribonucleic acid synthesis in the hamster. Endocrinology 122, 952-958.

Roy, S.K., Wang, S.-C. \& Greenwald, G.S. (1987) Radioreceptor and autoradiographic analysis of FSH, hCG and prolactin binding sites in primary to antral hamster follicles during the periovulatory period. J. Reprod. Fert. 79, 307-313.

Terranova, P.F. \& Greenwald, G.S. (1978) Steroid and gonadotropin levels during the luteal-follicular shift of the cyclic hamster. Biol. Reprod. 18, 170-175.

Received 28 November 1988 